\title{
Penerbit
}

\section{TOHAR MEDIA}
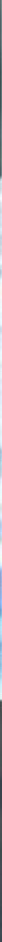

KIVIA ORGANIK FISIS

Ismail Marzuki

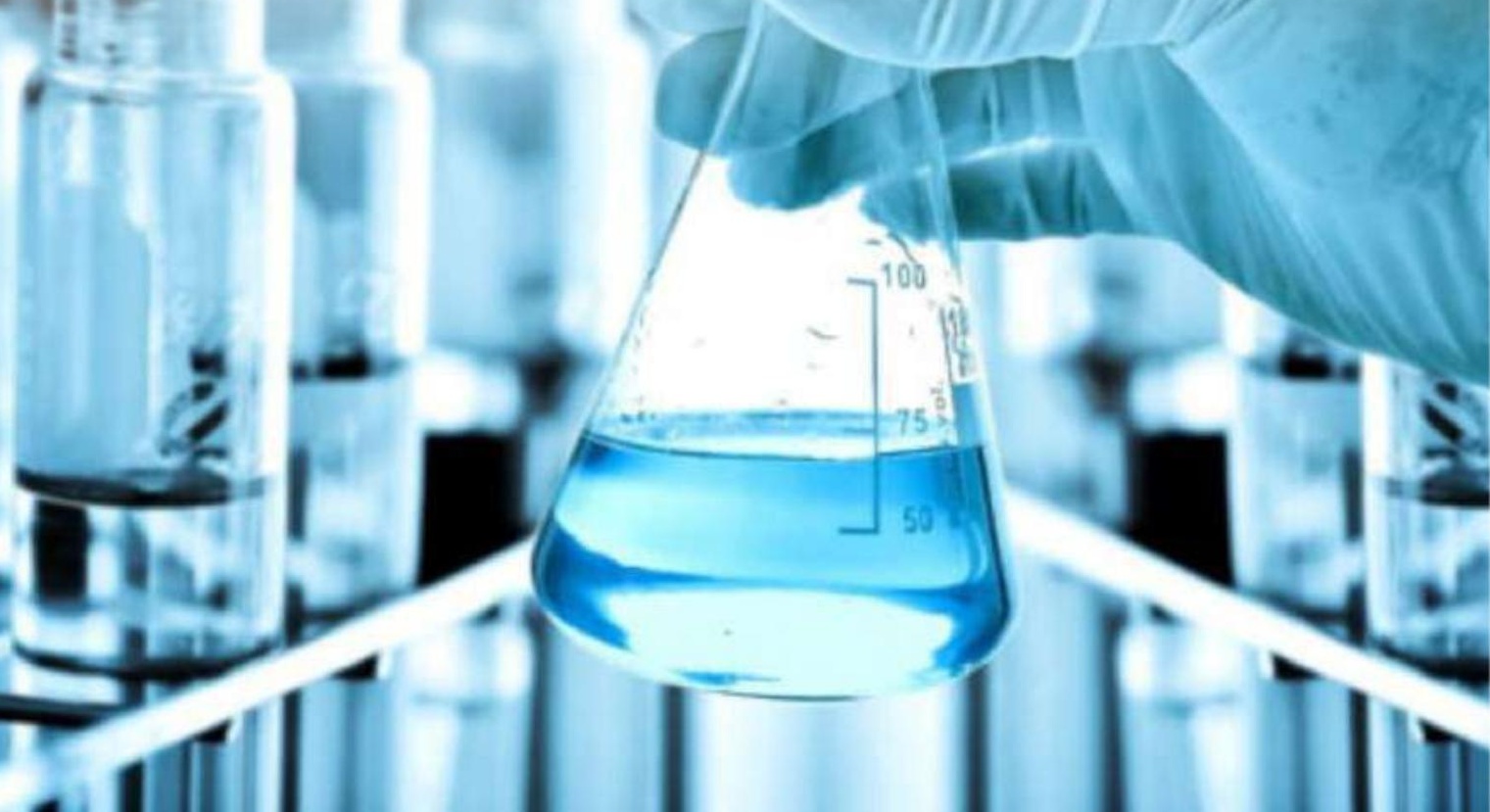




\section{PENGANTAR KIMIA ORGANIK FISIS}

Oleh :

ISMAIL MARZUKI

Editor:

Prof. Dr. Alfian Noor.,M.Sc 


\section{PENGANTAR KIMIA ORGANIK FISIS}

Penulis :

Ismail Marzuki

Editor :

Alfian Noor

ISBN

978-623-7485-64-3

Desain Sampul dan Tata Letak

Ai Siti Khairunisa

Penerbit

CV. Tohar Media

Anggota IKAPI No. 022/SSL/2019

\section{Redaksi :}

JL. Rappocini Raya Lr 11 No 13 Makassar

JL. Hamzah dg. Tompo. Perumahan Nayla Regency Blok D No.25 Gowa

Telp. (0411) 8987659 / 085243537215

Email : toharmedia@yahoo.com

Website : https://toharmedia.co.id

\section{Cetakan Pertama Februari 2021}

Nomor Catatan Ciptaan 000159527

Hak Cipta dilindungi undang-undang. Dilarang memperbanyak sebagian atau seluruh isi buku ini dalam bentuk apapun, baik secara elektronik maupun mekanik termasuk memfotocopy, merekam atau dengan menggunakan sistem penyimpanan lainnya, tanpa izin tertulis dari penerbit.

Undang-undang Nomor 19 Tahun 2002 Tentang Hak Cipta

1. Barang siapa dengan sengaja dan tanpa hak mengumumkan atau memperbanyak suatu ciptaan atau memberi izin untuk itu, dipidana dengan pidana penjara paling lama 7 (Tujuh) tahun dan/atau denda paling banyak Rp. 5.000.000.000,00 (Lima Miliar Rupiah)

2. Barang siapa dengan sengaja menyiarkan, memamerkan, mengedarkan, atau menjual kepada umum suatu ciptaan atau barang hasil pelanggaran hak cipta atau hak terkait sebagaimana dimaksud pada ayat 1 , dipidana paling lama 5 (lima tahun) dan/atau denda Rp. 500.000.000 (Lima Ratus Juta Rupiah). 
Puji syukur Kehadirat Allah SWT, Tuhan Yang Maha Esa Yang telah melimpahkan Rahmat dan Hidayah-nya, sehingga buku dengan judul Pengantar Kimia Organik Fisis. Buku ini diperuntukkan untuk menjadi pegangan Mahasiswa Kimia Sains, Teknik Kimia dan Farmasi khususnya mahasiswa pada tingkat pertama yang telah atau sementara memprogramkan mata kuliah Kimia Dasar. Ide awal penyusunan buku ini terinspirasi dari pengalaman mengajar mata kuliah Kimia Organik pada mahasiswa Kimia Sains, Farmasi dan Teknik Kimia serta dorongan beberapa teman sejawat dan mengajar matakuliah lanjutan dengan keluhan kesulitan dalam mengajar karena pemahaman dasar kimia organik mahasiswa sangat minim.

Buku ini disusun untuk memenuhi kebutuhan literatur mahasiswa khususnya pada tahun pertama. Pengantar Kimia Organik Fisis cocok menjadi pegangan mahasiswa kimia murni, teknik kimia dan bahkan mahasiswa Farmasi. Buku ini terdiri atas tujuh bab, yaitu; 1) Struktur dan Ikatan, 2) Ikatan Kovalen Polar: Asam-Basa, 3) Alkana dan Sikloalkana, 4) Alkena dan Alkuna, 5) Reaksi Organik, 6) Stereokimia dan 7) Alkohol, Eter dan Fenol.

Pada tiap bab disajikan dengan bahasa sederhana dan mudah dimengerti, berikut disertai dengan beberapa butir soal latihan pilihan berganda dan soal latihan uraian di setiap bab, dimaksudkan untuk mempermudah pemahaman mahasiswa dalam setiap materi. Setiap materi yang disajikan dengan menghubungkan contoh dalam kehidupan sehari-hari yang terkait dengan karakter dan perilaku mahasiswa, sehingga diharapkan lebih menarik dan mahasiswa tertarik untuk memahami kimia lebih baik, agar kesan sukar belajar kimia dapat di eliminir dan tidak lagi menjadi fobia d kalangan mahasiswa seperti yang terasa selama ini.

Terbitnya buku ini diharapkan bermanfaat dan berkontribusi membantu mahasiswa dalam mempelajari kimia 
organik. Sebab, keberhasilan bukan hanya ditentukan bagaimana model dan metode mengajar oleh setiap dosen tetapi juga ketekunan, ketertarikan dan usaha keras setiap peserta didik. Materi dalam buku ini disajikan dengan bahasa sederhana, sehingga diharapkan para peserta didik dapat menggunakan sebagai sarana belajar mandiri.

Terima kasih penulis ucapkan kepada kedua semua pihak yang banyak membantu dalam penulisan buku ini, terkhusus kepada Siti Aminah, SP., M.Si (istri), dan anak-anakku Putri Anugrah Ramadhani dan Putra Anugrah Ramadhan yang senantiasa mendampingi dan memberi semangat, juga kepada Fitra Anugrah Maulidhan (alm) dan Putra Al Ramzy Rafadhan (alm) yang telah dipanggil yang kuasa, telah memberi arti dan makna serta mewarnai kehidupan ini.

Terima kasih, semoga buku ini memberi manfaat untuk semuanya, Amiin.

Makassar, Januari 2021

Penulis 


\section{Pengantar Editor}

Mengutarakan sebuah gagasan, ide, pengetahuan seseorang yang dilakukan dengan menulis, baik berupa artikel sederhana, opini buku, cerpen, hikayat, risalah, biografi dan lain sebagainya adalah sebuah pekerjaan yang tidak gampang dan tidak banyak orang yang dapat mewujudkannya. Setiap orang yang sehat secara mental, dapat dipastikan memiliki gagasan, namun tidak semua orang dapat mengutarakan gagasan tersebut dengan menulis yang menghasilkan buku.

Buku ini mengurai dengan jelas tentang kimia organik fisis, dengan mengangkat topik-topik menarik. Sub-sub tema yang tepat dan spesifik disampaikan dalam bahasa yang lugas, sehingga menbacanya tidak lekas menimbulkan kebosanan. Informasi dalam buku ini cukup urgen bagi banyak kalangan, bukan hanya para akademisi, mahasiswa dan pelajar, tetapi dapat menyasar pada banyak pihak sebagai referensi dan juga dapat memenuhi kebutuhan pemerintah dan mahasiswa serta pelajar sebagai salah satu sumber belajar yang layak di baca.

Buku ini, juga sebagai bentuk penyebarluasan hasil-hasil pengalaman mengajar yang bersangkutan selama 15 tahun berturut-turut dan dipadukan dengan pengalaman riset yang telah dilakukan selama ini, karenanya buku ini bukan merupakan fiksi, opini atau hayalan, tetapi berupa karya sastra yang menyampaikan informasi ilmiah dan fakta-fakta riset yang berusaha mengangkat fenomena alam yang sering kita alami.

Review informasi yang menjadi isi buku ini tidak mudah dilakukan karena materi yang tersaji dalam buku ini merupakan kolaborasi wawasan pada banyak bidang, seperti biologi, kimia fisika, Biokimia dan farmasi serta bidang lainnya yang terkait, meski demikian buku ini menyuguhkan informasi ilmiah yang dapat menambah khasana dan wawasan kita. Apresiasi kepada Saudara Ismail Marzuki yang mampu menyampaikan dan berbagi pengalaman mengajar bidang kimia organik yang selama ini 
dilakukan sejak mengikuti pendidikan program doktoral hingga saat ini yang tetap konsisten mengajar bidang organik dan konsistensi riset tentang spons dan aplikasinya pada lingkungan.

E d i t o r,

Prof. Dr. Alfian Noor, M.Sc 
Halaman Sampul _I

\section{DAFTAR ISI}

Halaman Penerbit_ii

Prakata_iii

Kata Pengantar _v

Daftar Isi _vii

Bab 1. Struktur Ikatan _1
A. Pendahuluan _1
B. Struktur Atom _ 4
C. Orbital Atom _6
D. Konfigurasi Elektron Dalam Atom
E. Perkembangan Teori Ikatan Kimia _8
F. Ikatan Kimia _9
G. Ikatan Kovalen _11
H. Teori Orbital Molekul_13

Bab 2. Ikatan Kovalen Polar_31
A. Pendahuluan _31
B. Plarisasi dan Elektronegativitas _33
C. Momen Dipol_35
D. Muatan Formal_ 37
E. Asam dan Basa : Bronsted-Lowry _39
G. Asam dan Basa Organik _42
H. Resonansi_ 45
I. Menggambar Struktur Kimia _52

Bab 3. Senyawa Organik Alkana dan Sikloalkana _59
A. Pendahuluan_59
B. Gugus Fungsi _63
C. Alkana _66
D. Sikloalkana_72

Bab 4. Alkena dan Alkuna _77
A. Pendahuluan_79
B. Alkena
C. Adisi Hologen Pada Alkena
D. Pembentukan Holo Hidrin _106
E. Adisi Air Pada Alkena : Oksimerkurasi__107 
E. Adisi Air Pada Alkena : Oksimerkurasi_ _107

F. Hidroborasi__109

G. Reduksi Alkena : Hidrogenasi__111

H. Oksidasi Alkena : Hidroksilasi dan Pemutusan Ikatan _113

I. Adisi Radikal Pada Alkena : Polimerisasi _114

J. Polimerisasi Kationik _116

K. Alkuna _117

Bab 5. Overview Reaksi Organik _139

A. Pendahuluan _140

B. Macam-Macam Reaksi Organik _144

C. Mekanisme Reaksi Organik _145

D. Mekanisme Reaksi Radikal__147

E. Mekanisme Polar_149

F.Contoh Reaksi Polar :Adisi Hbr Pada Alkena _153

G. Reaksi: Penggunaan Tanda Panah Dalam Mekanisme Suatu Reaksi Polar _ 157

H. Keseimbangan, Kecepatan dan Perubahan Energi

Dalam Reaksi _160

I, Energi Disolasi Ikatan __161

J. Diagram Energi dan Transition State _163

K. Keadaan Intermediet _166

Bab 6. Streokimia_173
A. Pendahuluan_174
B. Enantimer dan Karbon Tetrahedral _ 176
C. Kiralitas _178
D. Aktivitas Optikal__180
E. Aturan Konfigurasi Spesifik : Aturan Cahn Ingold Prelog _181
F. Diastereomer _183
G. Senyawa Meso _184
H. Molekul Yang Memiliki Lebih Dari DuaPusat Kiral _185
I. Sifat Fisika Stereoisomer__186
J. Campuran Rasemat _186
K. Review Isomerisme_186 
L. Reaksi Stereokimia : Adisi Hbr Pada Alkena _189

M. Reaksi Stereokimia : Adisi Br2 Pada Alkena _190

N. Reaksi Stereokimia : Adisi Hbr Pada Alkena Kiral__191

O. Kiralitas Selain Pada Atom Karbon_ _186

P. Kiralitas Senyawa Alam _193

Q. Prokiralitas _194

Bab 7. Alkohol, Eter dan Fenol__201

A. Pendahuluan_202

B. Tata Nama Alkohol,Eter dan Fenol__204

C. Ikan Dalam Alkohol dan Eter _206

D. Sifat Fisik Alkohol dan Eter__208

E. Alkohol Sebagai Asam_208

F. Alkoksida dan Fenoksida_212

G. Pembuatan Alkohol dan Eter_213

H. Reaksi Subtitusi Alkohol_219

I. Reaksi Eliminasi Alkohol_223

J. Oksidasi Alkohol dan Fenol_ 226

K. Reaksi Subtitusi Eter__228

L. Reaksi Subtitusi Epoksida _231

Daftar Pustaka _239 


\section{STRUKTUR DAN IKATAN}

Pada Bab ini berisikan tentang beberapa pengertian dasar dalam kimia organik, yang terbagi dalam sub materi berikut:
A. Pendahuluan
B. Strukur Atom
C. Orbital Atom
D. Konfigurasi Elektron dalam Atom
E. Perkembangan Teori Ikatan Kimia
F. Ikatan Kimia
G. Ikatan kovalen
H. Teori Orbital Molekul

Tujuan Instruksional dari Pembelajaran ini adalah :

Mahasiswa dapat mengenal, mengerti, dan memahami pembentukan struktur kimia organik dan bagaimana mekanisme perikatan dan pembentukan ikatan kimia dalam setiap senyawa yang terbentuk, sehingga dapat memberi image pembentukan karakter positif mahasiswa

\section{A. Pendahuluan}

Mengapa kimia organik perlu dipelajari?. Jawabannya sangat sederhana, karena semua organisme hidup tersusun atas senyawa-senyawa organik yang senantiasa berinteraksi satu dengan lainnya untuk membentuk suatu senyawa yang dapat menunjang dalam proses kehidupan yang kita sebut dengan sel. Kumpulan sel dibentuk oleh komponen senyawa organik yakni karbohidrat, protein, lemak dan asam nukleat DNA yang "Pengantar Kimia Organik Fisis" 1 
mengontrol penurunan genetik, serta obat, semuanya merupakan senyawa organik, dengan demikian akan dapat ditelusuri proses pembelahan sel yang bersumber dari metabolisme yang di awal oleh nutrisi makanan oleh tubuh, sehingga pembelahan sel yang positif agar memberikan dapat positif pada perilaku sehari-hari kita dalam setiap aktivitas kehidupan.

Sejarah tentang kimia organik diawali sejak pertengahan abad 17. pada waktu itu, tidak dapat dijelaskan perbedaan antara senyawa yang diperoleh dari organisme hidup (hewan dan tumbuhan) dengan senyawa yang diperoleh dari bahan-bahan mineral.

Senyawa yang diperoleh dari tumbuhan dan hewan sangat sulit di isolasi. Jika diperoleh dengan pemurnian, senyawasenyawa yang diperoleh tersebut sangat mudah terdekomposisi dari pada senyawa yang diperoleh dari bahan-bahan mineral. Seorang ahli kimia dari Swedia, Torbern Bergman, pada tahun 1770 mengekspresikan penjelasan di atas sebagai perbedaan antara senyawa organik dan anorganik. Selanjutnya, senyawa organik diartikan sebagai senyawa kimia yang diperoleh dari makhluk hidup.

Ikatan kimia adalah sebuah proses fisika yang bertanggung jawab dalam interaksi gaya tarik menarik antara dua atom atau molekul yang menyebabkan suatu senyawa diatomik atau poliatomik menjadi stabil. Penjelasan mengenai gaya tarik menarik ini sangatlah rumit dan dijelaskan oleh elektrodinamika kuantum. Dalam prakteknya, para kimiawan biasanya bergantung pada teori kuantum atau penjelasan kualitatif yang kurang kaku (namun lebih mudah untuk dijelaskan) dalam menjelaskan ikatan kimia. Secara umum, ikatan kimia yang kuat diasosiasikan dengan transfer elektron antara dua atom yang berpartisipasi. Ikatan kimia menjaga molekul-molekul, kristal, dan gas-gas diatomik untuk tetap bersama. Selain itu ikatan kimia juga menentukan struktur suatu zat. 
Kekuatan ikatan-ikatan kimia sangatlah bervariasi. Pada umumnya, ikatan kovalen dan ikatan ion dianggap sebagai ikatan "kuat", sedangkan ikatan hidrogen dan ikatan van der Waals dianggap sebagai ikatan "lemah". Hal yang perlu diperhatikan adalah bahwa ikatan "lemah" yang paling kuat dapat lebih kuat daripada ikatan "kuat" yang paling lemah.

Banyak ahli kimia pada masa itu hanya menjelaskan perbedaan senyawa organik dan senyawa anorganik dalam hal bahwa senyawa organik harus mempunyai energi vital (vital force) sebagai hasil dari keaslian mereka dalam tubuh makhluk hidup. Salah satu akibat dari energi vital ini adalah para ahli kimia percaya bahwa senyawa organik tidak dapat dibuat maupun di manipulasi di laboratorium sebagaimana yang dapat dilakukan terhadap senyawa anorganik. Teori vitalitas ini kemudian mengalami perubahan ketika Michael Chevreul (1816) menemukan sabun sebagai hasil reaksi antara basa dengan lemak hewani. Lemak hewani dapat dipisahkan dalam beberapa senyawa organik murni yang disebut dengan asam lemak. Untuk pertama kalinya satu senyawa organik (lemak) diubah menjadi senyawa lain (asam lemak dan gliserin) tanpa intervensi dari energy vital.

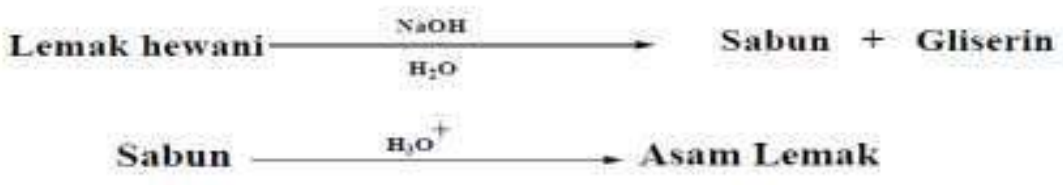

Beberapa tahun kemudian, teori vitalitas semakin melemah ketika Friedrich Wohler (1828) mampu mengubah garam anorganik, ammonium sianat, menjadi senyawa organik yaitu urea yang sebelumnya telah ditemukan dalam urin manusia.

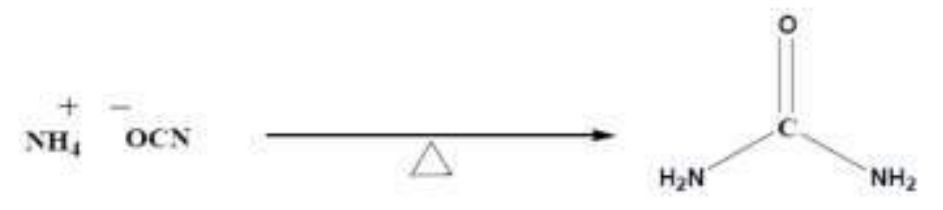


Atom terpenting yang dipelajari dalam kimia organik adalah atom karbon. Meskipun demikian, atom lainnya juga dipelajari seperti hidrogen, nitrogen, oksigen, fosfor, sulfur, dan atom lainnya. Akan tetapi mengapa atom karbon sangat spesial? Atom karbon merupakan termasuk dalam golongan $4 \mathrm{~A}$, karbon memiliki empat elektron valensi yang dapat digunakan untuk membentuk empat ikatan kovalen. Di dalam tabel periodik, atom karbon menduduki posisi tengah dalam kolom periodenya. Atom di sebelah kiri karbon memiliki kecenderungan memberikan elektron sedangkan di sebelah kanannya memiliki kecenderungan menarik elektron.

Atom karbon dapat berikatan satu dengan lainnya membentuk rantai panjang atau cincin. Karbon, sebagai elemen tunggal mampu membentuk bermacam senyawa, dari yang sederhana seperti metana, hingga senyawa yang sangat kompleks misalnya DNA yang terdiri dari sepuluh hingga jutaan atom karbon. Jadi, senyawa karbon tidak hanya diperoleh dari organisme hidup saja. Kimiawan modern saat ini sudah mampu mensintesis senyawa karbon di dalam laboratorium. Contohnya: obat, pewarna, polimer, pengawet makanan, pestisida, dan lainlain. Saat ini, kimia organik di definisikan sebagai senyawa yang mengandung atom karbon.

\section{B. Struktur Atom}

Mempelajari kimia organik, akan lebih mudah jika terlebih dahulu kita mengulas kembali beberapa pengertian dasar yang umum tentang atom dan pembentukan ikatan, termasuk orbital molekul. Atom terdiri dari nukleus dengan muatan positif yang dikelilingi muatan negtif dari elektron pada jarak yang relatif jauh. Nukleus terdiri atas partikel subatomik yang disebut neutron, bermuatan netral, dan proton, bermuatan positif. Meskipun memiliki diameter yang sangat kecil - sekitar $10^{-14}$ hingga $10^{-15} \mathrm{~m}$. Nukleus berperan penting terhadap semua massa dari atom. Elektron memiliki massa yang dapat diabaikan dan mengelilingi 


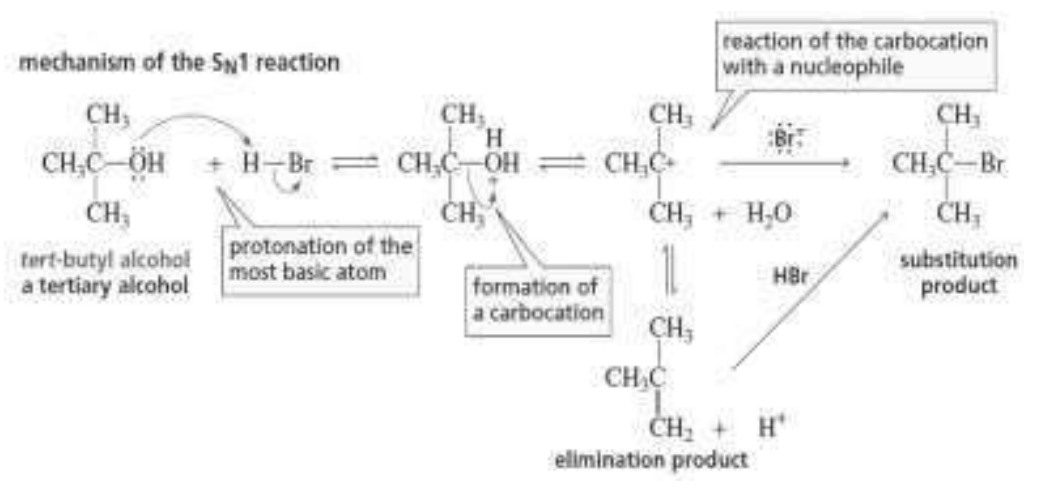

Gambar 7.32 Contoh mekanisme reaksi pembentukan alkil halide dari alkohol mengikuti $\mathrm{SN}_{1}$ reaksi eliminasi

Alkohol tersier menjalani reaksi substisui dengan hidrogen halida lebih cepat dari alkohol sekunder karena karbokation tersier lebih mudah terbentuk daripada karbokation sekunder. Dengan demikian, reaksi alkohol tersier dengan hidrogen halida dapat terjadi dengan mudah pada suhu kamar, sedangkan reaksi alkohol sekunder dengan hidrogen halida harus dipanaskan untuk bereaksi pada laju reaksi yang sesuai.

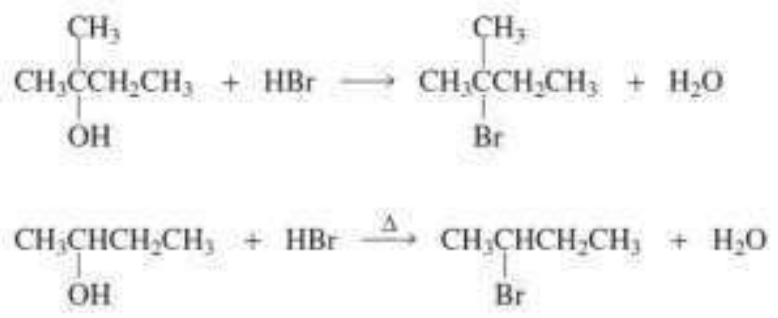

Gambar 7.33 Reaksi konversi alkohol tersier dan sekunder menjadi alkil halide menggunakan pereaksi hydrogen halida

Alkohol primer tidak dapat menjalani reaksi $S_{N} 1$ karena karbokation primer terlalu tidak stabil untuk dibentuk. Oleh karena itu, ketika alkohol primer bereaksi dengan hidrogen halida, ia harus melalui reaksi $S_{N} 2$. 
mechanism of the $S_{\mathrm{N}} 2$ reaction

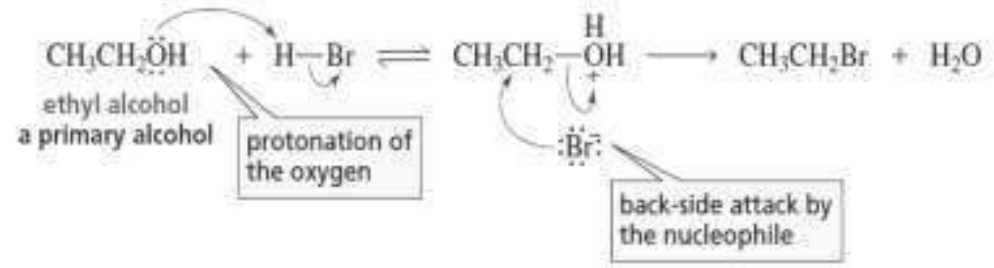

Gambar 7.34 Mekanisme protonasi alkil alkohol menghasilkan alkil halide dengan intermediate protonasi mengikuti mekanisme $\mathrm{SN}_{2}$

Hanya produk substitusi yang diperoleh. Bukan produk eliminasi yang dibentuk karena ion halida, meskipun sebagai nukleofili yang baik, namun merupakan basa lemah, dan basa kuat diperlukan dalam reaksi E2 untuk menghilangkan proton dari karbon- $\beta$. (Ingat bahwa karbon- $\beta$ adalah karbon yang berdekatan karbon yang terikat pada gugus pergi.) Ketika $\mathrm{HCl}$ digunakan sebagai pengganti $\mathrm{HBr}$ atau $\mathrm{HI}$, reaksi $\mathrm{S}_{\mathrm{N}} 2$ menjadi lambat karena $\mathrm{Cl}^{-}$merupakan nukleofili yang jelek dari $\mathrm{Br}^{-}$atau $\mathrm{I}^{-}$. Laju reaksi dapat ditingkatkan dengan menggunakan katalis.

$$
\mathrm{CH}_{3} \mathrm{CH}_{2} \mathrm{CH}_{2} \mathrm{OH}+\mathrm{HCl} \stackrel{\mathrm{ZnCl}_{2}}{\longrightarrow} \mathrm{CH}_{3} \mathrm{CH}_{2} \mathrm{CH}_{2} \mathrm{Cl}+\mathrm{H}_{2} \mathrm{O}
$$

Gambar 7.35 Contoh reaksi alkohol primer dengan reagen hydrogen klorida menghasilkan alkil halida

$\mathrm{Zn}^{2+}$ merupakan asam Lewis dengan kompleks yang kuat dengan pasangan elektron menyendiri pada oksigen. Ini melemahkan ikatan $\mathrm{C}-\mathrm{O}$ dan membuat gugus pergi yang baik.

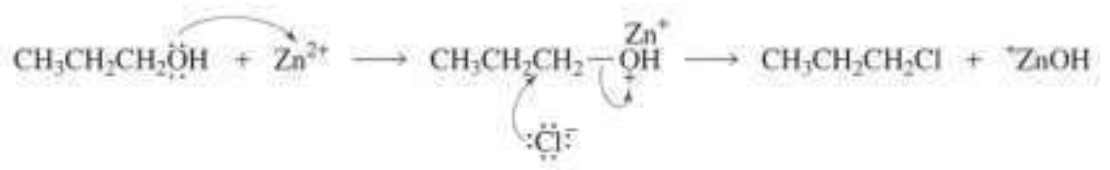

Gambar 7.36 Reaksi aktivasi karbon-oksigen dengan penggunaan katalis ion $\mathrm{Zn}$ dalam suasana asam 
Karena reaksi alkohol sekunder atau tersier dengan hidrogen halida adalah reaksi $S_{N} 1$, maka karbokation terbentuk sebagai intermediet. Oleh karena itu, kita harus memeriksa kemungkinan penataan ulang karbokation ketika memprediksi produk reaksi substitusi. Ingat bahwa penataan ulang karbokation dapat terjadi jika itu mengarah pada pembentukan karbokation yang lebih stabil. Misalnya, produk utama reaksi 3-metil-2-butanol dengan $\mathrm{HBr}$ adalah 2-bromo-2-metilbutana, karena pergeseran 1,2-hidrida mengubah karbokation sekunder yang awalnya dibentuk menjadi karbokation tersier yang lebih stabil.

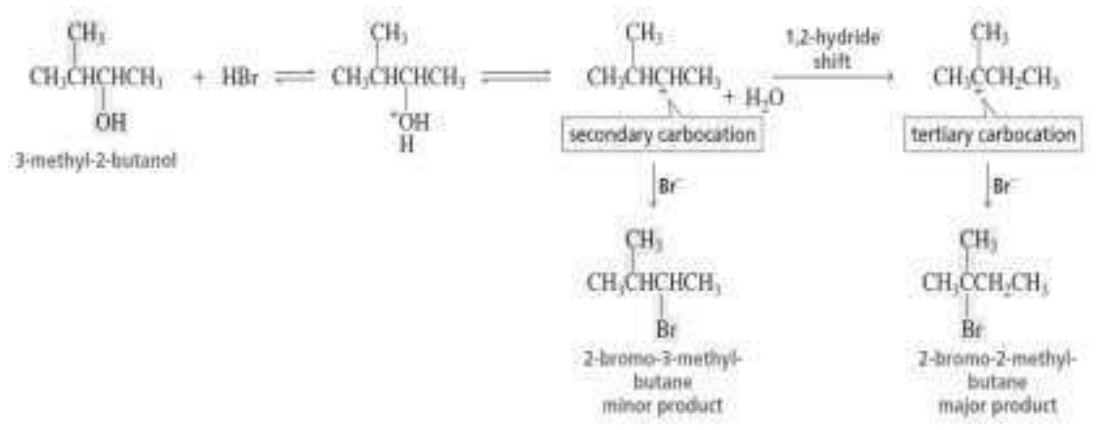

Gambar 7.37 Mekanisme penataan ulang karbokation menghasilkan karbokation stabil dengan dua produkalkil halida bersaing

\section{Reaksi Eliminasi Alkohol}

Alkohol dapat didehidrasi dengan memanaskannya bersama asam kuat. Contohnya, bila etanol dipanaskan pada suhu $180^{\circ} \mathrm{C}$ dengan sedikit asam sulfat pekat, diperoleh etilena dengan rendemen (perolehan) yang baik.

$$
\mathrm{H}-\underset{\text { etanol }}{\mathrm{CH}_{2} \mathrm{CH}_{2}}-\mathrm{OH} \stackrel{\mathrm{H}^{5}, 1800 \mathrm{C}}{\longrightarrow} \underset{\text { etilema }}{\stackrel{\mathrm{CH}_{2}}{\mathrm{CH}_{2}}+\mathrm{H}} \sim \mathrm{OH}
$$

Gambar 7.38 Reaksi eliminasi suatu alkohol primer menjadi etilen dan molekul air sebagai produk samping

Jenis reaksi ini, yang dapat digunakan untuk membuat alkena, merupakan kebalikan dari reaksi hidrasi. Ini merupakan reaksi 
eliminasi dan dapat berlangsung baik melalui mekanisme E1 maupun E2, bergantung pada golongan alkoholnya.

Alkohol tersier terdehidrasi melalui mekanisme E1. Suatu $t$-butil alkohol sebagai contohdehidrasi alkohol tersier. Perubahan tersebut dengan mengikuti beberapa tahapan perubahan, yakni: Tahap pertama melibatkan protonasi yang cepat dan reversibel pada gugus hidroksil.

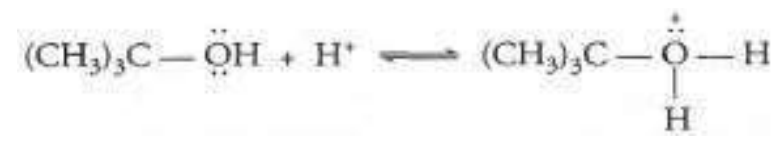

Gambar 7.39 Protonasi gugus gugus hidroksil berlangsung secara reversibel

Tahap kedua ialah ionisasi (langkah penentu laju reaksi), dengan air sebagai gugus pergi, terjadi dengan mudah sebab karbokation yang dihasilkannya berstruktur tersier.

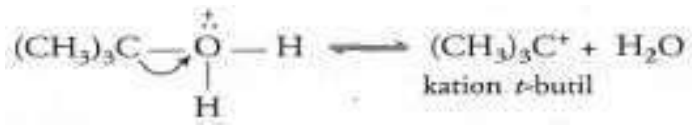

Gambar 7.40 Ionisasi oksigen dengan mengeliminasi molekul air membentuk karbokation tersier

Proses ini menyebabkan lepasnya proton dari ikatan atom karbon di sebelah karbon positif untuk menuju pada reaksi akhir dari reaksi eliminasi

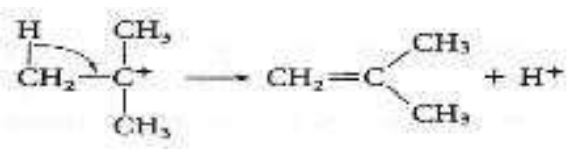

Gambar 7.41 Lepasnya proton dan membentuk produk etilena sebagai produk akhir dalam reaksi eliminasi

Reaksi dehidrasi keseluruhan ialah jumlah dari ketiga langkah tersebut. 


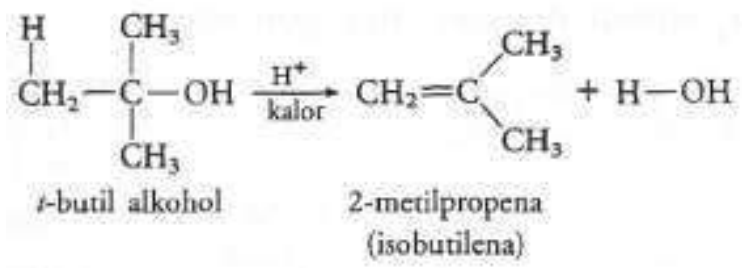

Gambar 7.42 Rekasi dehidrasi secara lengkap terjadi dalam suasana panas menghasilkan suatu alkena

Zat antara pada reaksi alkohol primer. Keadaan intermediet (zat antara) berupa karbokation primer dapat dihalangi dengan menggabungkan kedua langkah terakhir dalam mekanisme tersebut. Lepasnya air dan satu proton tetangga secara serentak terjadi dalam mekanisme E2.

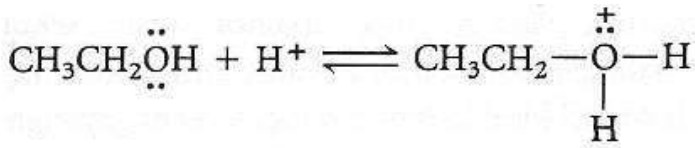

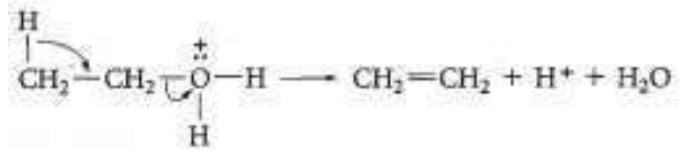

Gambar 7.43 Reaksi protonasi pembentukan karbokation sebagai zat antara dan selanjutnya pelepasan molekul air

Penting untuk di diingat mengenai dehidrasi alkohol ialah bahwa (1) reaksi ini dimulai dengan protonasi pada gugus hidroksil (artinya, alkohol bertindak sebagai basa) dan (2) kemudahan dehidrasi alkohol ialah $3^{\circ}>2^{\circ}>1^{\circ}$ (urutannya sama seperti kestabilan karbokation).

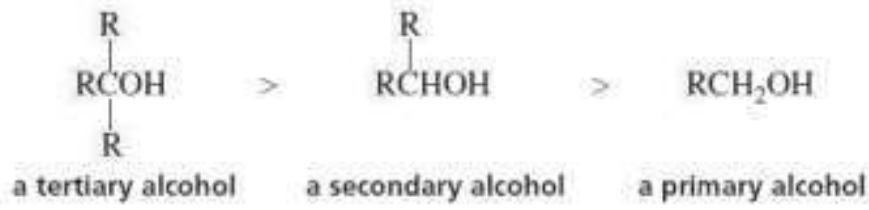

Gambar 7.44 Kemudahan terjadinya reaksi dehidrasi (eliminasi molekul air) alkohol 
Kadang-kadang, satu alkohol menghasilkan dua atau lebih alkena sebab proton yang lepas sewaktu dehidrasi dapat berasal dari atom karbon mana saja yang bersebelahan dengan atom karbon pembawa gugus hidroksil. Contohnya, 2-metil-2-butanol dapat memberikan dua alkena.

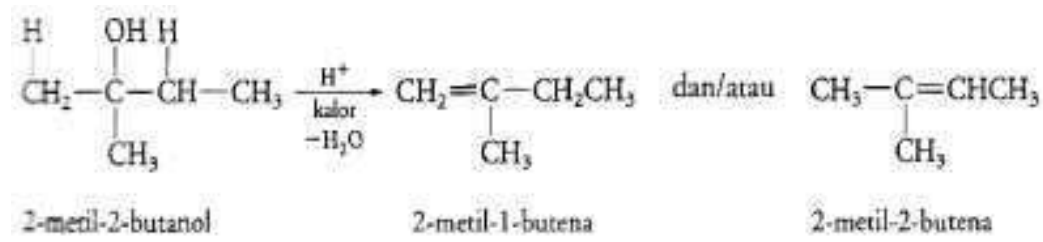

Gambar 7.45 Rekasi bersaing alkohol yang menghasilkan dua produk alkena

Produk alkena dengan ikatan rangkap yang paling tersubstitusi biasanya lebih dominan. Yang dimaksud dengan "paling tersubstitusi" ialah alkena dengan jumlah gugus alkil terbanyak pada karbon yang berikatan rangkap. Jadi, pada contoh yang ditunjukkan ini, produk utamanya ialah 2-metil-2-butena.

\section{J. Oksidasi Alkohol Dan Fenol}

\section{Oksidasi Alkohol}

Alkohol dengan sekurang-kurangnya satu hidrogen melekat pada karbon pembawa hidroksil dapat dioksidasi menjadi senyawa karbonil. Alkohol primer menghasilkan aldehid, yang dapat dioksidasi lebih lanjut menjadi asam karboksilat. Alkohol sekunder menghasilkan keton. Perhatikan bahwa sewaktu alkohol dioksidasi menjadi aldehid atau keton dan kemudian menjadi asam karboksilat, jumlah ikatan di antara atom karbon reaktif dan atom oksigen meningkat dari satu menjadi dua dan menjadi tiga. Dengan kata lain, kita katakan bahwa bilangan oksidasi karbon itu naik sewaktu kita bergerak dari alkohol menjadi aldehida atau keton, lalu menjadi asam karboksilat. Alkohol tersier, karena tidak memiliki atom hidrogen pada karbon pembawa hidroksil, tidak menjalani jenis oksidasi ini. 

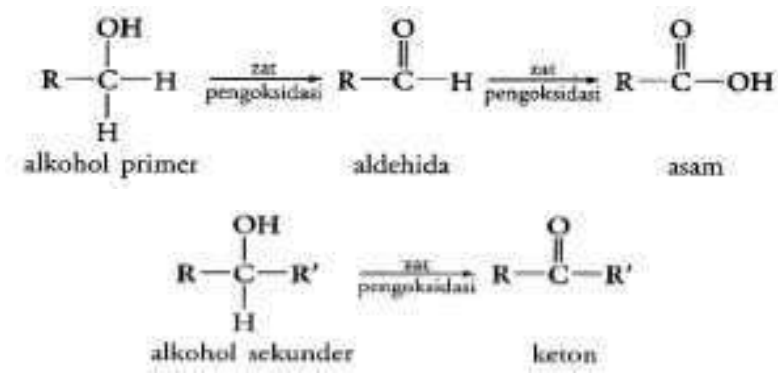

Gambar 7.46 Rekasi oksidasi perubahan alkohol menjadi aldehid dan akhirnya menjadi asam karboksilat

Zat pengoksidasi yang sering digunakan di laboratorium untuk alkohol ialah anhidrida kromat, $\mathrm{CrO}_{3}$, yang dilarutkan dalarn asarn sulfat berair (reagen Jones). Aseton digunakan sebagai pelarut dalam oksidasi ini. Contohnya ialah:

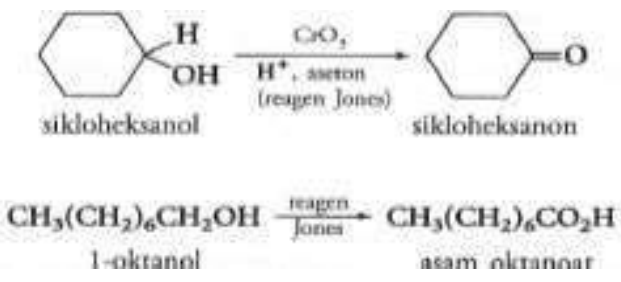

Gambar 7.47 Contoh reaksi perubahan alkohol menjadi produk senyawa mengandung karbonil menggunakan zat

pengoksida anhidrida kromat

Suatu contoh reaksi perubahan alkohol primer dengan menggunakan zat pengoksida, namun reaksi oksidasi dapat dihentikan pada tahap aldehida jika digunakan reagen khusus, seperti piridinium klorokromat $(\mathrm{KCl})$, sebagaimana ditunjukkan pada reaksi berikut:

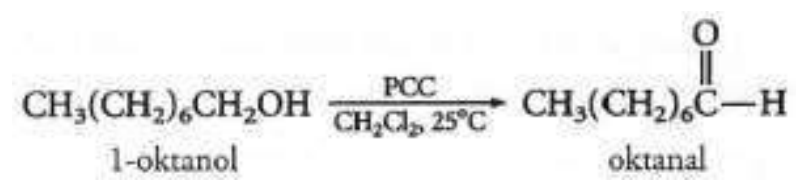

Gambar 7.48 Konversi alkohol menjadi aldehid menggunakan PCC 
PCC dibuat dengan melarutkan $\mathrm{CrO}_{3}$ dalam asam hidroklorida kemudian ditambahkan piridina:

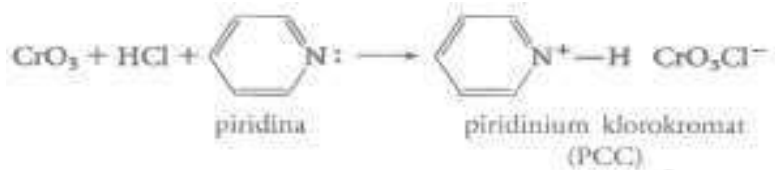

$\backslash$ Gambar 7.49 Rekasi pembuatan PCC

1. Oksidasi Fenol

Fenol mudah dioksidasi. Jika suatu sampel yang dibiarkan terpapar dengan oksigen di udara dalam beberapa jam sering menjadi sangat berwarna karena terbentuknya produk oksidasi atau terjadi reaksi oksidasi. Senyawa hidrokuinon (1,4-dihidroksibenzena), reaksi ini mudah dikendalikan untuk menghasilkan 1,4-benzokuinon (sering disebut kuinon).

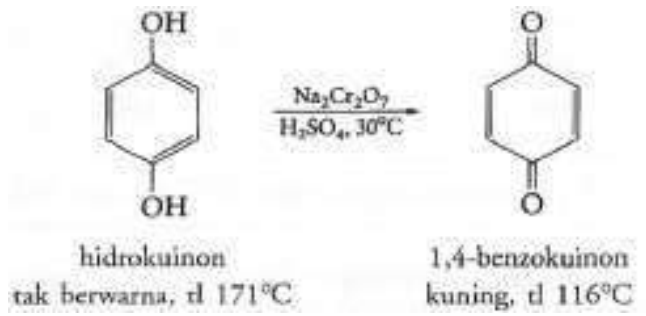

Gambar 7.50 Rekasi konversi hidrokuinon menjadi benzokuinon

Hidrokuinon dan senyawa yang berhubungan digunakan dalam cuci-cetak foto. Senyawa tersebut mereduksi ion perak yang belum terpapar ke cahaya menjadi perak logam (dan kemudian dioksidasi menjadi kuinon). Oksidasi hidrokuinon menjadi kuinon bersifat reversibel; interkonversi ini berperan penting dalam beberapa reaksi oksidasi-reduksi biologis.

\section{K. Reaksi Subtitusi Eter}

Gugus -OR dari eter dan gugus -OH dari alkohol memiliki sifat kebasaan yang hampir sama, karena asam konjugasi mereka memiliki nilai $\mathrm{p} K_{a}$ yang sama. $\left(\mathrm{p} K_{a} \mathrm{CH}_{3} \mathrm{OH}\right.$ adalah 15,5 dan $\mathrm{p} K_{a}$ 
$\mathrm{H}_{2} \mathrm{O}$ adalah 15,7.) Kedua gugus merupakan basa kuat, sehingga keduanya merupakan gugus pergi yang sangat jelek. Akibatnya, alkohol dan eter sama-sama tidak reaktif terhadap substitusi nukleofilik.

$$
\begin{array}{cc}
\mathrm{R}-\mathrm{O}-\mathrm{H} & \mathrm{R}-\mathrm{O}-\mathrm{R} \\
\text { an alcohol } & \text { an ether }
\end{array}
$$

Gambar 7.51 Contoh rumus umum suatu alkohol dan eter

Banyak pereaksi yang digunakan untuk mengaktifkan alkohol terhadap substitusi nukleofilik (misalnya, $\mathrm{SOCl}_{2}, \mathrm{PCl}_{3}$ ) tidak dapat digunakan untuk mengaktifkan eter. Ketika alkohol bereaksi dengan agen pengaktivasi seperti sulfonil klorida, proton dipisahkan dari intermediet dalam reaksi tahap kedua dan menghasilkan sulfonat ester yang stabil.

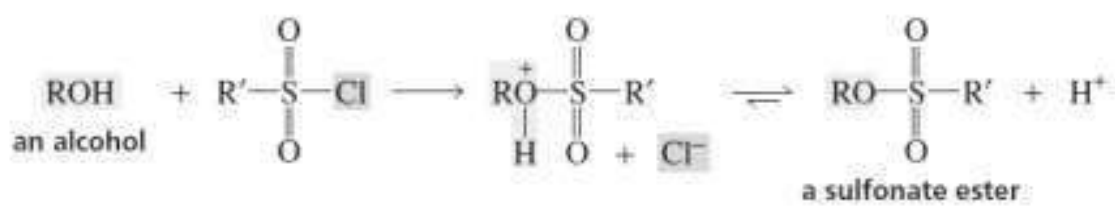

Gambar 7.52 Reaksi pengaktifan alkohol menggunakan zat pengaktivasi melalui mekanisme SN

Ketika eter bereaksi dengan sulfonil klorida, namun atom oksigen tidak memiliki proton yang dapat terdisosiasi. Gugus alkil (R) tidak dapat dipisahkan, sehingga sulfonat ester stabil tidak terbentuk. Sebaliknya, material awal yang lebih stabil terbentuk.<smiles>[R][CH][C-]O[R]</smiles>

Gambar 7.53 Rekasi perubahan eter menjadi ester yang stabil menggunakan reagen sulfonil klorida 
Seperti halnya alkohol, eter dapat diaktifkan dengan protonasi, sehingga eter dapat menjalani reaksi substitusi nukleofilik dengan $\mathrm{HBr}$ atau $\mathrm{HI}$. Seperti halnya alkohol, reaksi eter dengan hidrogen halida berjalan lambat, dan campuran reaksi dipanaskan agar reaksi terjadi pada laju reaksi yang wajar.

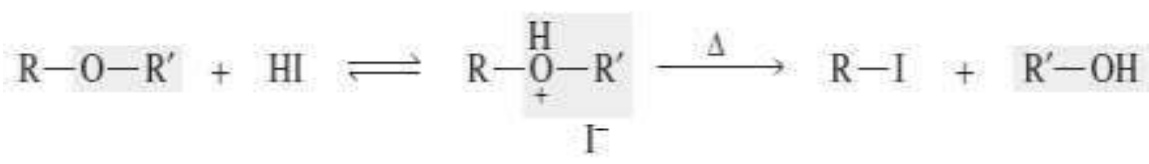

Gambar 7.54 Rekasi eter melalui mekanisme protonasi menghasilkan produk akhir suatu alkohol

Langkah pertama dalam pemecahan eter oleh $\mathrm{HI}$ atau $\mathrm{HBr}$ adalah protonasi oksigen eter. Ini mengubah gugus pergi $\mathrm{RO}^{-}$ yang lebih basa menjadi gugus pergi $\mathrm{ROH}$ yang kurang basa. Apa yang terjadi berikutnya dalam mekanisme tergantung pada struktur eter. Jika kepergian dari gugus pergi membuat karbokation relatif stabil (misalnya, karbokation tersier), reaksi $\mathrm{S}_{\mathrm{N}} 1$ terjadi-gugus pergi ditinggalkan, dan ion halida bergabung dengan karbokation tersebut.

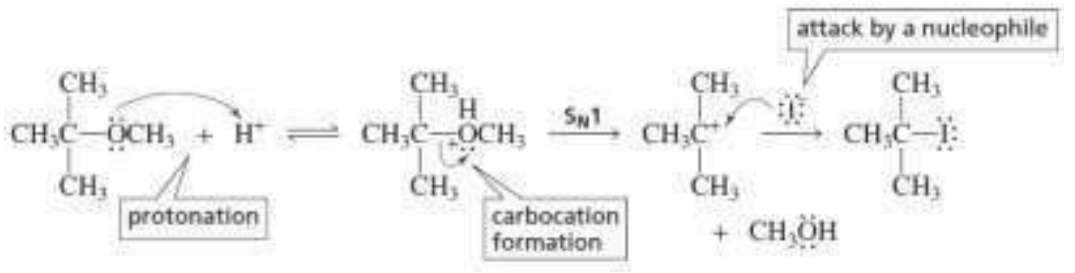

Gambar 7.55 Mekanisme reaksi pembentukan alkil halide melalui protonasi dan produk intermediet karbokation

Namun, jika kepergian dari gugus pergi akan membuat karbokation tidak stabil (misalnya, metil, vinil, aril atau karbokation primer), maka gugus pergi tersebut tidak dapat ditinggalkan. Ini harus digantikan oleh ion halida. Dengan kata lain, reaksi $S_{N} 2$ terjadi. Serangan ion halida secara preferensial kurang sterik karena terhalang oleh dua gugus alkil. 


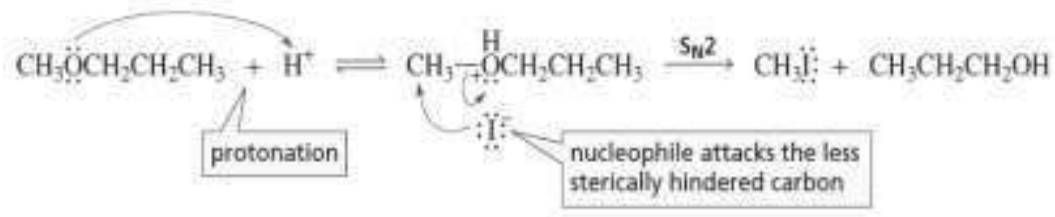

Gambar 7.56 Rekasi pembentukan alkohol dari eter melaui jalur protonasi dan kehadiran serangan nukleofilik

Pemutusan eter oleh $\mathrm{HI}$ atau $\mathrm{HBr}$ terjadi lebih cepat jika reaksi dapat berlangsung dengan satu jalur. Jika ketidakstabilan karbokation membutuhkan reaksi untuk mengikuti jalur $S_{N} 2$, pemecahan ini dapat terjadi lebih cepat dengan HI daripada menggunakan molekul $\mathrm{HBr}$ karena I- merupakan nukleofil yang lebih baik daripada $\mathrm{Br}^{-}$. Hanya produk substitusi dihasilkan karena kehadiran basa dalam campuran reaksi (ion halida dan $\mathrm{H}_{2} \mathrm{O}$ ) terlalu lemah untuk memisahkan proton dalam reaksi E2, dan setiap alkena yang terbentuk dalam reaksi E1 akan menjalani adisi elektrofilik dengan $\mathrm{HBr}$ atau $\mathrm{HI}$ untuk membentuk alkil halida yang sama seperti yang diperoleh dari reaksi substitusi. $\mathrm{HCl}$ pekat tidak dapat memecah eter karena $\mathrm{Cl}^{-}$merupakan nukleofili yang terlalu jelek.

\section{Reaksi Subtitusi Epoksida}

Eter dengan atom oksigen yang bergabung menjadi cincin beranggota tiga dinamakan epoksida atau oksirana. Nama umum epoksida menggunakan nama umum alkena diikuti kata "oksida". Epoksida yang paling sederhana adalah etilena oksida.

$$
\begin{gathered}
\mathrm{H}_{2} \mathrm{C}=\mathrm{CH}_{2} \\
\text { ethylene }
\end{gathered}
$$

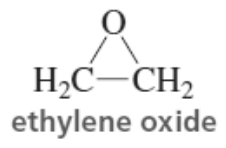

$$
\underset{\text { propylene }}{\mathrm{H}_{2} \mathrm{C}=\mathrm{CHCH}_{3}}
$$

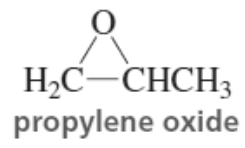

Gambar 7.57 Contoh melekul etilen membentuk epoksida dengan kehadiran oksigen membentuk cincin berongga 
Meskipun epoksida dan eter memiliki gugus pergi yang sama, namun epoksida jauh lebih reaktif daripada eter dalam reaksi substitusi nukleofilik karena tegangan dalam cincin beranggota tiga berkurang ketika cincin terbuka. Oleh karena itu, epoksida lebih mudah menjalani reaksi pembukaan cincin dengan berbagai macam nukleofili.

Epoksida, seperti eter lainnya, bereaksi dengan ion halida. Pada langkah pertama dari reaksi, oksigen nukleofilik diprotonasi oleh asam. Epoksida yang terprotonasi kemudian diserang oleh ion halide, karena epoksida jauh lebih reaktif dibandingkan eter, reaksi berlangsung mudah pada suhu kamar. (Ingat bahwa reaksi eter dengan hidrogen halida membutuhkan panas).

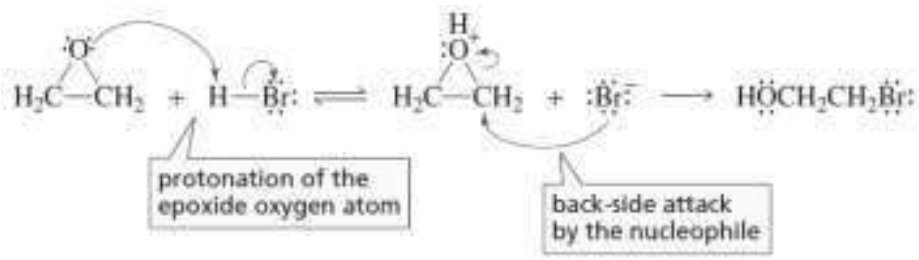

Gambar 7.57 Rekasi protonasi epoksida dan menghasilkan zat antara dengan serangan nukleofil bromide menghasilkan alkohol bromida

Epoksida yang terprotonasi sangat reaktif sehingga mereka dapat dibuka oleh nukleofil yang jelek, seperti $\mathrm{H}_{2} \mathrm{O}$ dan alkohol. $\left(\mathrm{HB}^{+}\right.$adalah sembarang asam dalam campuran reaksi; B: adalah sembarang basa).
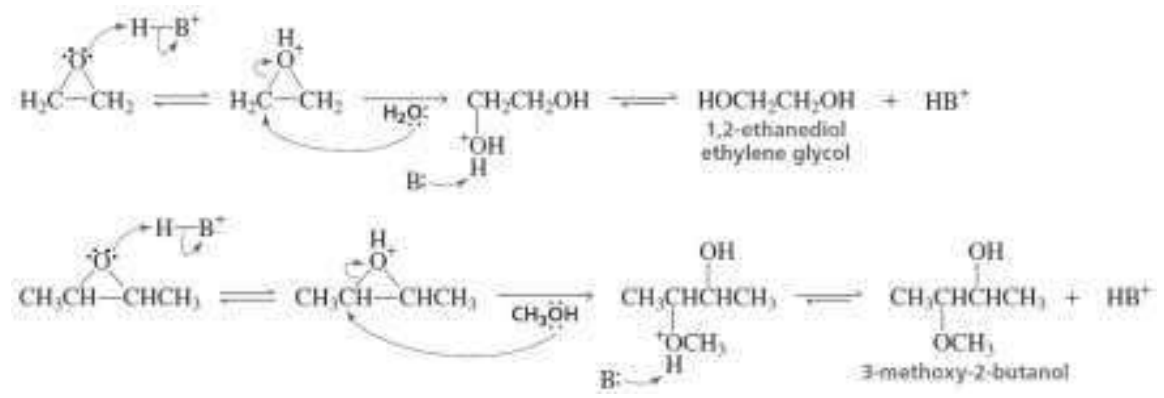
Gambar 7.58 Pembukaan cincin epoksida oleh suatu nukleofil dapat terjadi jika epoksida mengalami protonasi terlebi dahulu

Jika substituen yang berbeda melekat pada dua karbon dari epoksida yang terprotonasi (dan nukleofili adalah sesuatu selain $\mathrm{H}_{2} \mathrm{O}$ ), maka produk yang diperoleh dari serangan nukleofilik pada posisi 2 dari cincin oksirana akan berbeda dari yang diperoleh dari serangan nukleofilik pada posisi 3. Produk utamanya adalah salah satu akibat dari serangan nukleofilik pada karbon yang lebih tersubstitusi.

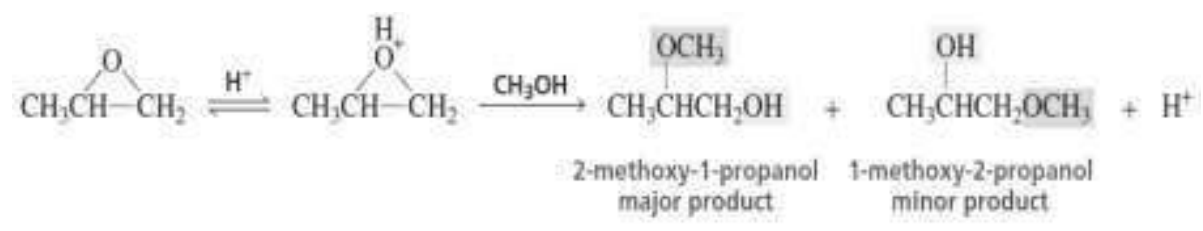

Gambar 7.59 Protonasi epoksida menghasilkan produk antara karbokation dan dua produk akhir yang saling bersaing

a. Eter Mahkota

Perkembangan senyawa polieter mengundang banyak perhatian dari kalangan ilmuan khususnya para kimiawan banyak. Perhatian ini ditujukan pada polieter tipe makrosiklik (cincin besar) yang biasa disebut molekul mahkota atau eter mahkota, karena molekul tersebut merupakan senyawa eter. Contoh molekul eter mahkota sebagaimana tampak berikut:

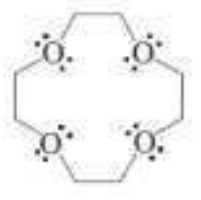

[12]-crown-4 cavity diameter $=1.2-1.5 \mathrm{~A}$

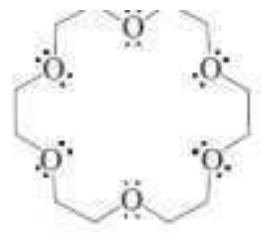

[18]-crown-6 cavity diameter $=2.6-3.2 \mathrm{~A}$

Gambar 7.60 Contoh eter mahkota dengan sudut 12 dan 18

Senyawa seperti ini disebut eter mahkota (crown ether) mengingat molekulnya yang berbentuk seperti mahkota. Angka dalam tanda kurung siku dalam penamaan umumnya 
menunjukkan ukuran cincin, dan angka yang terakhir menunjukkan jumlah oksigen. Oksigen biasanya dipisahkan satu dengan lainnya oleh dua atom karbon.

Eter mahkota memiliki sifat unik untuk membentuk kompleks dengan ion positif $\left(\mathrm{Na}^{+}, \mathrm{K}^{+}\right.$, dan seterusnya). Ion positif masuk di dalam cincin makrosiklik secara selektif, bergantung pada ukuran cincin dan ukuran ion. Contohnya, [18] mahkota-6 mengikat $\mathrm{K}^{+}$lebih erat daripada $\mathrm{Na}^{+}$yang lebih kecil (terlalu longgar) atau $\mathrm{Cs}^{+}$yang lebih besar (terlalu besar sehingga tidak masuk ke dalam rongga). Demikian halnya, [15] mahkota-5 mengikat $\mathrm{Na}^{+}$, dan [12] mahkota-4 mengikat $\mathrm{Li}^{+}$. Eter mahkota bertindak sebagai inang untuk ion tamunya.

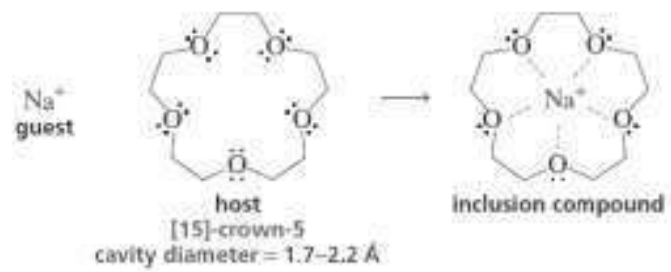

Gambar 7.61 Contoh pengikatan ion positif eter mahkota-5 yang lebih kuat dibandingkan pada pengikatan ion positif lainnya karena rongga yang tidak sesuai, terlalu besar atau terlalu kecil

Kemampuan mengompleks ini begitu kuat sehingga senyawa ionik dapat dilarutkan dalarn pelarut organik yang mengandung eter mahkota. Contohnya, kalium permanganat $\left(\mathrm{KMnO}_{4}\right)$ larut dalam air tetapi tidak larut dalarn benzena. Akan tetapi, jika sedikit disikloheksil [18] mahkota-6 dilarutkan dalam benzena, dimungkinkan untuk mengekstraksi kalium permanganat dari air ke dalam benzena! Hasil berupa "benzena ungu," mengandung ion permanganat yang pada dasarnya bebas dan tak tersolvasi, yang merupakan zat pengoksidasi kuat.

Pengikatan ion logam secara selektif oleh senyawa makrosiklik sangat penting di alam. Beberapa antibiotika, seperti nonaktin, memiliki cincin besar yang mengandung atom oksigen 
yang jaraknya beraturan. Nonaktin (yang mengandung empat cincin tetrahidrofuran disambungkan oleh empat ikatan ester) secara selektif mengikat $\mathrm{K}^{+}$(dengan kehadiran $\mathrm{Na}^{+}$) dalam media berair, dengan demikian memungkinkan mengangkut $\mathrm{K}^{+}$secara selektif (tetapi tidak $\mathrm{Na}^{+}$) melewati membran sel.

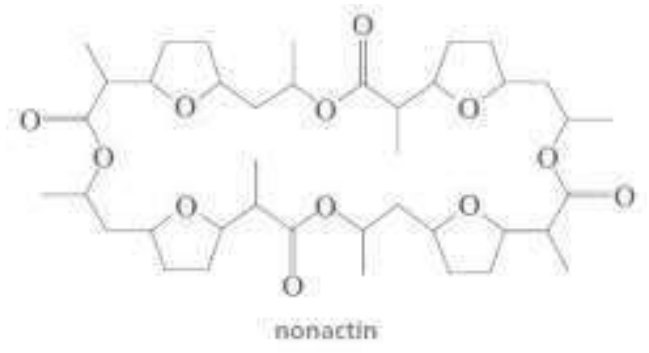

Gambar 7.62 Molekul Nonactin dibentuk oleh atom oksigen dengan jarak teratur

b. Tiol dan Sulfida

Sulfur terletak tepat di bawah oksigen pada tabel berkala dan sering dapat menggantikannya dalam struktur organik. Gugus - SH, disebut gugus sulfhidril ialah gugus fungsi tiol. Tiol dinamai sebagai berikut:

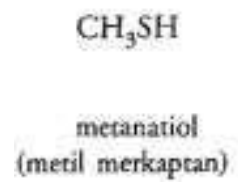

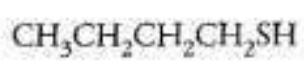

1-butanatiol (n-buril merkaptan)

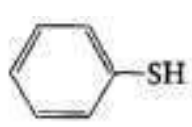

tiofenol (fenil merkaptan)

Gambar 7.63 Contoh senyawa-senyawa tiol atau molekul sulfida

Tiol kadang-kadang disebut merkaptan, yaitu penamaan yang merujuk reaksinya dengan ion merkurium membentuk garam merkurium, yang dinamakan merkaptida.

$$
2 \mathrm{RSH}+\mathrm{HgCl}_{2} \longrightarrow \begin{aligned}
& (\mathrm{RS})_{2} \mathrm{Hg}+2 \mathrm{HCl} \\
& \text { merkantida }
\end{aligned}
$$

Gambar 7.64 Reaksi tiol dengan merkuri klorida menghasilkan merkaptida 
Alkil tiol dapat dibuat dari alkil halida melalui substitusi nukleofilik dengan ion sulfhidril.

$$
\mathrm{R}-\mathrm{X}+\mathrm{SH} \longrightarrow \mathrm{R}-\mathrm{SH}+\mathrm{X}-
$$

Gambar 7.65 Reaksi pembuatan alkil tio dari alkil halida

Barangkali ciri yang paling menonjol dari tiol ialah bau busuknya yang menyengat. Contohnya, tiol $\mathrm{CH}_{3} \mathrm{CH}=\mathrm{CHCH}_{2} \mathrm{SH}$ dan $\left(\mathrm{CH}_{3}\right)_{2} \mathrm{CHCH}_{2} \mathrm{CH}_{2} \mathrm{SH}$, ialah bau dari hewan segung. Struktur yang berkaitan dengan tiol $\left(\mathrm{CH}_{3}\right)_{2} \mathrm{C}=\mathrm{CHCH}_{2} \mathrm{SH}$ baru-baru ini diketahui sebagai bau seperti segung dan cita rasa dari bir yang terpapar ke cahaya.

Tiol lebih asam daripada alkohol. Contohnya, $\mathrm{p} K_{\mathrm{a}}$ etanatiol adalah 10,6 sedangkan etanol 15,9. Dengan demikian, tiol bereaksl dengan basa berair menghasilkan tiolat.

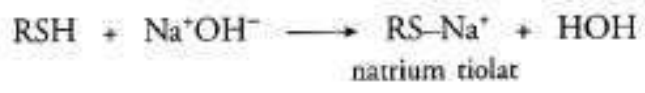

Gambar 7.66 Reaksi tiol dengan suatu basa

Tiol mudah dioksidasi menjadi disulfida, yaitu senyawa yang mengandung ikatan $S-S$, oleh zat pengoksidasi ringan seperti hidrogen peroksida atau iodin. Disulfida yang terdapat di alam yang Anda kenali baunya ialah dialil disulfida $\left(\mathrm{CH}_{2}=\mathrm{CHCH}_{2} \mathrm{~S}-\mathrm{SCH}_{2} \mathrm{CH}=\mathrm{CH}_{2}\right)$, yang menyebabkan bau bawang putih tampak segar.

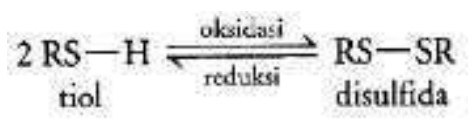

Gambar 7.67 Reaksi reversible tiol membentuk disulfide dan sebaliknya

Reaksi yang ditunjukkan pada reaksi di atas dapat dibalik dengan berbagai zat pereduksi. Karena protein mengandung jembatan disulfida, reaksi oksidasi-reduksi yang reversibel ini dapat digunakan untuk memanipulasi struktur protein. 
1. Manakah isomer alkohol $\mathrm{C}_{4} \mathrm{H}_{10} \mathrm{O}$ yang dapat dibuat dengan hidrogenasi aldehid? Yang dapat dibuat dengan hidrogenasi keton? Yang tidak dapat dibuat dengan hidrogenasi senyawa karbonil?

2. Berikan struktur ester yang dapat menghasilkan campuran yang mengandung jumlah mol yang sama dari 1-propanol dan 2-propanol pada reduksi dengan lithium aluminium hidrida!

3. Prediksikan produk organik utama dari masing-masing reaksi berikut:
(a) $\mathrm{ClCH}_{2} \mathrm{CH}_{2} \mathrm{CH}_{2} \mathrm{CH}_{2} \mathrm{OH} \frac{\mathrm{K}_{2} \mathrm{Cr}_{2} \mathrm{O}_{7}}{\mathrm{H}_{2} \mathrm{SO}_{4}, \mathrm{H}_{2} \mathrm{O}}$
(b) $\mathrm{CH}_{3} \mathrm{CHCH}_{2} \mathrm{CH}_{2} \mathrm{CH}_{2} \mathrm{CH}_{2} \mathrm{CH}_{2} \mathrm{CH}_{3} \frac{\mathrm{Na}_{2} \mathrm{Cr}_{2} \mathrm{O}_{7}}{\mathrm{H}_{2} \mathrm{SO}_{4}, \mathrm{H}_{2} \mathrm{O}}$
(c) $\mathrm{CH}_{3} \mathrm{CH}_{2} \mathrm{CH}_{2} \mathrm{CH}_{2} \mathrm{CH}_{2} \mathrm{CH}_{2} \mathrm{CH}_{2} \mathrm{OH} \frac{\mathrm{PCC}}{\mathrm{CH}_{2} \mathrm{Cl}_{2}}$

4. Setiap eter berikut telah terbukti atau dicurigai menjadi mutagen, yang berarti dapat menyebabkan mutasi pada sel uji. Tuliskan struktur dari masing-masing eter berikut:

(a) Klorometil metil eter
(b) 2-(klorometil)oksirana epiklorohidron)
(c) 3,4-Epoksi-1-butena (2-viniloksirana)

5. Tulis persamaan yang menggambarkan dua metode yang berbeda di mana benzil etil eter dapat dibuat oleh sintesis eter Williamson! 
238 "Pengantar Kimia Organik Fisis" 


\section{Daftra Pustaka}

Atkins, Peter W. and Julio de Paula Physical Chemistry, 4th Edition, Wiley-VCH, Weinheim 2006, ISBN 978-3-527-31546-8

Atkins, Peter, 1997. Chemistry: Molecules, Matter and Change. New York: W. H. Freeman \& Co.. hlm. 294- 295. ISBN 0-71673107-X.

Barton, D. H. R.; McCombie, S. W. (1975). "A new method for the deoxygenation $\mathrm{f}$ secondary alcohols". J. Chem. Soc., Perkin Trans. 1 (16): 1574-1585. doi:10.1039/P19750001574..

Barton, D. H. R.; McCombie, S. W. (1975). A new method for the deoxygenation of secondary alcohols. J. Chem. Soc., Perkin Trans. 1 (16): 1574-1585. doi:10.1039/P19750001574.

Barton, D. H. R.; McCombie, S. W. (1975). A new method for the deoxygenation of secondary alcohols. J. Chem. Soc., Perkin Trans. 1 (16): 1574-1585. doi:10.1039/P19750001574.

Brückner, Reinhard Reaktionsmechanismen. 3rd ed., Spektrum Akademischer Verlag, München 2004, ISBN 3-8274-1579-9

Bruice, P. Y. (2000). Organic Chemistry (4th ed.). United States of America: McGraw-Hill.

Bruice, P.Y., Organic Chemistry, 4th edition,

Bruice, P.Y., Organic Chemistry, 4th edition,

Bruice, P.Y., Organic Chemistry, 4th edition,

Carey, F. A. (2000). Organic Chemistry (4th ed.). United States of America: McGraw-Hill.

Carl R. Nave, 2005. HyperPhysics. Retrieved May 18, 2005.

Carl R. Nave, 2005. HyperPhysics. Retrieved May 18, 2005.

Corey, E. J. (1988). "Robert Robinson Lecture. Retrosynthetic thinking?essentials and examples". Chemical Society Reviews 17: 111. doi:10.1039/CS9881700111. 
Crich, David; Quintero, Leticia (1989). Radical chemistry associated with the thiocarbonyl group. Chem. Rev. 89 (7): 1413-1432. doi:10.1021/cr 00097a001.

Crich, David; Quintero, Leticia (1989). Radical chemistry associated with the thiocarbonyl group. Chem. Rev. 89 (7): 1413-1432. doi:10.1021/cr 00097a001Bruice, P.Y., Organic Chemistry, 4th edition,

Fessenden, R.J. dan Fessenden, J.S., 1986, Organic Chemistry, 3rd edition

Fessenden, R.J. dan Fessenden, J.S., 1986, Organic Chemistry, 3rd edition,

Fessenden, R.J. dan Fessenden, J.S., 1986, Organic Chemistry, 3rd edition,

Fessenden, R.J. dan Fessenden, J.S., Terjemahan A. Hadyana Pudjaatmaka, 1986, Organic Chemistry, 3rd, Erlangga, Jakarta

Fessenden, R.J. dan Fessenden, J.S., Terjemahan A. Hadyana Pudjaatmaka, 1984, Organic Chemistry, Jilid 2, Erlangga, Jakarta

Fessenden, R.J. dan Fessenden, J.S., Terjemahan A. Hadyana Pudjaatmaka, 1986, Organic Chemistry, 3 edt, Erlangga, Jakarta

Fessenden, R.J. dan Fessenden, J.S., Terjemahan A. Hadyana Pudjaatmaka, 1984, Organic Chemistry, Jilid 2, Erlangga, Jakarta

Fessenden, R.J. dan Fessenden, J.S., Terjemahan A. Hadyana Pudjaatmaka, 1986, Organic Chemistry, 3rd, Erlangga, Jakarta

Hart, H., Craine, L. E., Hart, D. J., (2003). Kimia Organik: Suatu Kuliah Singkat (12th Ed.) Jakarta: Erlangga 
HKBAI Indonesia, Wikipedia Indonesia Stereokimia, Akses 19 Maret 2011

HKBAI Indonesia, Wikipedia Indonesia Stereokimia, Akses 19 Maret 2011

HKBAI Indonesia, Wikipedia Indonesia Stereokimia, Akses 19 Maret 2011

HKBAI Indonesia, Wikipedia Indonesia Stereokimia, Akses 19 Maret 2011

Hoffman, R.V., 2004, Organic Chemistry An Intermediate Text, 2nd edition, John Willey and Sons Inc, New Mexico

Hoffman, R.V., 2004, Organic Chemistry An Intermediate Text, 2nd edition, John Willey and Sons Inc, New Mexico

Hoffman, R.V., 2004, Organic Chemistry An Intermediate Text, 2nd edition, John Willey and Sons Inc, New Mexico

Hoffman, R.V., 2004, Organic Chemistry An Intermediate Text, 2nd edition, John Willey and Sons Inc, New Mexico

Hoffman, R.V., 2004, Organic Chemistry An Intermediate Text, 2nd edition, John Willey and Sons Inc, New Mexico

Hoffman, R.V., 2004, Organic Chemistry An Intermediate Text, 2nd edition, John Willey and Sons Inc, New Mexico

International Union of Pure and Applied Chemistry (1995). Cycloalkanes. Compendium of Chemical Terminology Internet edition.

International Union of Pure and Applied Chemistry. "elementary reaction". Compendium of Chemical Terminology Internet edition.

IUPAC Recommendations on Organic \& Biochemical Nomenclature, Symbols, Terminology, etc. (includes IUBMB Recommendations for biochemistry) 
IUPAC, Commission on Nomenclature of Organic Chemistry (1993). "R-2.2.1: Hydrocarbons". A Guide to IUPAC Nomenclature of Organic Compounds (Recommendations 1993). Blackwell Scientific. ISBN 0632034882. Diakses pada 12 Februari 2007.

IUPAC, Commission on Nomenclature of Organic Chemistry (1993). R-2.2.1: Hydrocarbons. A Guide to IUPAC Nomenclature of Organic Compounds (Recommendations 1993). Blackwell Scientific. ISBN 0632034882. Diakses pada 12 Februari 2007.

James, H. H., 1933. The Ground State of the Hydrogen Molecule. Journal of Chemical Physics (American Institute of Physics) 1: 825 - 835.

James, H. H., 1933. The Ground State of the Hydrogen Molecule. Lournal of Chemical Physics (American Institute of Physics) 1: 825 - 835.

John E. Lesch The German chemical industry in the twentieth century, Springer, 2000, ISBN 0-7923-6487-2 p. 170

John J. McKetta, Guy E Weismantel Encyclopedia of Chemical Processing and Design: Volume 67 - Water and Wastewater Treatment: ISBN 0-8247-2618-9, p. 109

Laidler, K. J.,1993. The World of Physical Chemistry, Oxford University Press, p. 347

Marcellino Rudyanto, 2004, Sintesis Organik, Cetakan Pertama, Airlangga University Press

Marcellino Rudyanto, 2004, Sintesis Organik, Cetakan Pertama, Airlangga University Press

Marcellino Rudyanto, 2004, Sintesis Organik, Cetakan Pertama, Airlangga University Press

Marcellino Rudyanto, 2004, Sintesis Organik, Cetakan Pertama, Airlangga University Press

242 "Pengantar Kimia Organik Fisis" 
Marcellino Rudyanto, 2004, Sintesis Organik, Cetakan Pertama, Airlangga University Press

March, Jerry (1985). Advanced Organic Chemistry, Reactions, Mechanisms and Structure (edisi ke-third Edition). John Wiley \& Sons. ISBN 0-471-85472-7.

McMurry, J. (2000). Organic Chemistry (5th ed.). United State of America: Brooks/Cole.

McMurry, J., 1984., Organic Chemistry, Wadsworth Inc., California.

McMurry, J., 1984., Organic Chemistry, Wadsworth Inc., California.

McMurry, J., 1984., Organic Chemistry, Wadsworth Inc., California.

McMurry, J., 2004, Organic Chemistry, Wadsworth Inc., California.

McMurry, J., 2004, Organic Chemistry, Wadsworth Inc., California.

McMurry, J., 2004, Organic Chemistry, Wadsworth Inc., California.

McMurry, J., 2004, Organic Chemistry, Wadsworth Inc., California.

McMurry, J., 2004, Organic Chemistry, Wadsworth Inc., California.

McMurry, J., 2004, Organic Chemistry, Wadsworth Inc., California.

Mumma, M.J. (1996). "Detection of Abundant Ethane and Methane, Along with Carbon Monoxide and Water, in Comet C/1996 B2 Hyakutake: Evidence for Interstellar Origin". Science 272 (5266): 1310. doi:10.1126/ science .272.5266.1310. PMID $\underline{\text { 8650540. }}$.

Mumma, M.J. (1996). Detection of Abundant Ethane and Methane, Along with Carbon Monoxide and Water, in Comet C/1996 B2 Hyakutake: Evidence for Interstellar Origin". Science 272 (5266): 1310. doi:10.1126/science. 272.5266.1310

Nunuk, H.,S., 2008. Menentukan struktur molekul senyawa melalui analisis data spektroskopi. Jurusan Kimia F. Mipa Unhas, Makassar 
Odian, G. (2009). General, Organic, and Biochemistry for Nursing and Allied Health (2nd Ed.). United States of America: McGraw-Hill.

Organic Chemistry IUPAC Nomenclature.Rules A-41, A-42: Spiro Hydrocarbons

http://www.acdlabs.com/iupac/nomenclature/79/r79_196.ht $\mathrm{m}$

Organic Chemistry IUPAC Nomenclature.Rules A-51, A-52, A-53, A-54:Hydrocarbon Ring Assemblies http://www.acdlabs. com/iupac/ nomenclature/79/r79_158.htm

Pauling, L., 1960. The Nature of the Chemical Bond. Cornell University Press.

Pauling, L., 2008. The Nature of the Chemical Bond: A Documentary History. Retrieved February 29, 2008.

Pauling, L., 2008. The Nature of the Chemical Bond: A Documentary History. Retrieved February 29, 2008.

R. T. Morrison, R. N. Boyd (1992). Organic Chemistry (edisi ke-6th). New Jersey: Prentice Hall. ISBN 0-13-643669-2.

Rittner, D., Bailey, R. A. (2005). Encyclopedia of Chemistry. United States of America: Facts On File, Inc.

S. R. Hartshorn, Aliphatic Nucleophilic Substitution, Cambridge University Press, London, 1973. ISBN 0-521-09801-7 pp. 1 ff

Stefanus Layli Prasojo, 2010. Kimia Organik I untuk Mahasiswa Farmasi, Yogyakarta

Stefanus Layli Prasojo, 2010. Kimia Organik I untuk Mahasiswa Farmasi, Yogyakarta

Stefanus Layli Prasojo, 2010. Kimia Organik I untuk Mahasiswa Farmasi, Yogyakarta

Stefanus Layli Prasojo, 2010. Kimia Organik I untuk Mahasiswa Farmasi, Yogyakarta

244 "Pengantar Kimia Organik Fisis" 
Stefanus Layli Prasojo, 2010. Kimia Organik I untuk Mahasiswa Farmasi, Yogyakarta

Stefanus Layli Prasojo, 2010. Kimia Organik I untuk Mahasiswa Farmasi, Yogyakarta

Titan: Arizona in an Icebox? Emily Lakdawalla, 21 January 2004, verified 28 March Weinhold, F.; Landis, C., 2005. Valency and bonding, Cambridge, pp. 96-100.

Usman. H., 2007. Kimia Bahan Alam, Jur. Kimia F.MIPA Unhas, Makassar

Usman. H., Kimia Bahan Alam, Jur. Kimia F.MIPA Unhas, Makassar

Usman. H., Kimia Bahan Alam, Jur. Kimia F.MIPA Unhas, Makassar

W. Locke, 1997. Introduction to Molecular Orbital Theory. Retrieved May 18, 2005.

W. Locke, 1997. Introduction to Molecular Orbital Theory. Retrieved May 18, 2005.

Weinhold, F.; Landis, C., 2005. Valency and bonding, Cambridge, pp. 96-100.

Weyer, Jost (1973). "Neuere Interpretationsmglichkeiten der Alchemie" (dalam bahasa German). Chemie in unserer Zeit 7 (6): 177. doi:10.1002/ciuz.19730070604.

William Reusch. "Nomenclature - Alkanes". Virtual Textbook of Organic Chemistry.

Yamamura, S.; Nishiyama, S. Comp. Org. Syn. 1991, 8, 309313.(Review)

Zenta, F., 2009. Kimia Organik Fisis I, Jurusan Kimia F. MIPA Unhas, Makassar

Zenta, F., 2009. Kimia Organik Fisis I, Jurusan Kimia F. MIPA Unhas, Makassar 
Zenta, F., 2009. Kimia Organik Fisis I, Jurusan Kimia F.Mipa Unhas, Makassar

Zenta, F., 2009. Kimia Organik Fisis I, Jurusan Kimia F.Mipa Unhas, Makassar

Zenta, F., 2009. Kimia Organik Fisis I, Jurusan Kimia F.Mipa Unhas, Makassar 


\section{Riwayat Penulis}

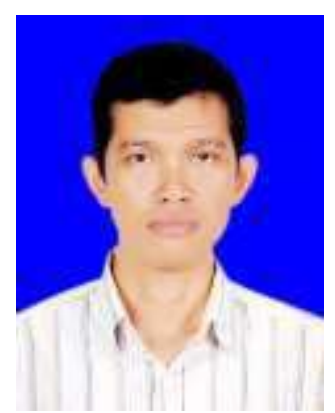

Dr. Ismail Marzuki, S.Si., M.Si, lahir di Kabere-Enrekang, $235 \mathrm{~km}$ ke Utara Kota Makassar, pada 03 Juli 1973. Mengikuti pendidikan formal Tingkat Sekolah Dasar

Negeri 19 Kabere Tahun 1980-1986, Sekolah Menegah Pertama (SMP) Kabere Tahun 19861989, dan pendidikan Menengah Atas (SMA 1 Enrekang) 19891992. Gelar sarjana Sains (kimia) disandang tahun 1999, di Jurusan Kimia F.MIPA UNHAS, dan gelar Magister Sains (M.Si) diraih pada Tahun 2003.

Gelar Doktor diperoleh pada tahun 2016, Program Pascasarjana UNHAS dalam waktu tempuh 3, 4 tahun. Karir akademisi dimulai tahun 2000 hingga sekarang. Status PNS (Dosen) diperoleh pada Tahun 2005, unit kerja Kopertis Wil. IX Sulawesi di pekerjakan pada Akademi Analis Kimia (AAK) Yapika Makassar. Karir pengelola kampus diawali Tahun 2002-2003, sebagai Direktur bidang Akademik AAK Yapika dan jabatan Direktur AAK Yapika Tahun 2003-2008.

Akhir Tahun 2008-2012, menjabat sebagai Ketua Bidang Akademik Sekolah Tinggi Ilmu Kesehatan (STIKES) Yapika. Tahun 2014 - 2015 sebagai Ketua Sekolah Tinggi Ilmu Kesehatan (STIKES) Bina Mandiri Gorontalo yang saat ini telah naik status menjadi Universitas Bina Mandiri Gorontalo. Saat ini mengabdi pada Universitas Fajar (UNIFA), Makassar sejak Tahun 2015 pada 
Prodi home base Teknik Kimia, Universitas Fajar. Tugas tambahan yang di amanahkan oleh UNIFA adalah Pimpinan Redaksi Jurnal Techno Entrepreneur Acta (2016-sekarang), Ketua Unit Pusat Karir UNIFA (Tahun 2016-2018), Ketua Ketua Lembaga Penjaminan Mutu Internal UNIFA (2019-2020), dan Dekan Fakultas Pascasarjana UNIFA (2020-sekarang). Pengalaman menulis buku pertama kali Tahun 2008 dengan judul Kimia Keperawatan, kemudian Biokimia Kesehatan, Lalu Kimia Farmasi, selanjutnya buku berjudul Analisis dan Instrumentasi Kimia, semuanya merupakan buku ajar. Buku kelima sekaligus buku referensi pertama berjudul Eksplorasi Spons Indonesia: Seputar Kepulauan Spermonde, dan Buku ke-6, berjudul: Aplikasi Mikro simbiosis Spons dalam Bioremediasi Lingkungan yang merupakan hasil penelitian dalam tiga tahun terakhir 2016-2019. Saat ini telah mengoleksi 23 buku yang telah ditulis dengan berbagai judul baik sebagai penulis tunggal, penulis kolaborasi maupun penulis dalam bookchapter.

Pengalaman menulis lainnya yang oleh penulis adalah aktif menyampaikan gagasan pada kolom opini Harian Fajar, Blogspot dan tempahan menulis artikel ilmiah yang telah dipublikasikan baik pada jurnal Nasional dan Internasional bereputasi, juga banyak menghabiskan waktu mendampingi mahasiswa sebagai pembimbing riset tugas akhir, menulis proposal PKM dan kewirausahaan mahasiswa. 


\section{Sinopsis \\ PENGANTAR KIMIA ORGANIK FISIS}

Buku Ajar Pengantar Kimia Organik Fisis disajikan sebagai bahan ajar dikhususkan untuk mahasiswa dalam tingkat Pertama Bersama atau mahasiswa tingkat pertama di jenjang perguruan tinggi. Pengantar Kimia Organik Fisis dapat menjadi salah satu buku pegangan untuk berbagai bidang kajian, mulai dari mereka yang mendalami rumpun ilmu-ilmu sains, teknik, pertanian, kesehatan. Pengantar Kimia Organik Fisis ini juga penting untuk dimiliki oleh para mahasiswa yang baru memulai mendalami ilmu kimia khususnya yang bercita-cita menjadi seorang saintis, khususnya peminatan bidang kimia organik.

Tambahan materi dan data dalam buku ini diperkaya hasil-hasil penelitian dan review jurnal dan materi kimia organik yang telah lama diajarkan selama ini. Konten dan konteks susunan materi pengantar kimia organik fisis ini disajikan dalam susunan Bab secara dan menggunakan Bahasa sederhana pula agar mudah dipahami oleh setiap pembaca. Susunan Bab terdiri atas: Bab (1) Struktur dan ikatan; (2) Ikatan Kovalen Polar: Asam-Basa; (3) Senyawa Organik Alkana dan Sikloalkana; (4) Alkena dan Alkuna; (5) Overview Senyawa Organik; (6) Stereokimia; dan (7) Alkohol, Eter dan Fenol. Pilihan materi kajian sebagaimana tersebut di atas dimaksudkan untuk memberikan pemahaman kepada setiap mahasiswa yang memiliki persinggungan dalam pengembangan bidang kajian masing-masing, sehingga dengan kombinasi-kombinasi kajian materi dari aspek pengkajian bidang ilmu yang bervariasi diharapkan dapat memperkaya dan berkontribusi dalam pengembangan ilmu kimia organik kontemporer. Dinamika ilmu pengetahuan dewasa ini memang tidak dapat di pungkiri sesuatu kebutuhan persilangan pengkajian dari beberapa sudut pandang, agar penyajian materi pembelajaran kimia organik semakin maju dengan lahirnya model-model pembelajaran yang dapat berjalan beriringan dan paralel dengan kemajuan ilmu lain dan juga dapat menjawab tantangan perkembangan global dewasa ini.

\section{TOHAR MEDIA}

No Anggota IKAPI : 022/SSL/2019

Workshop : JL. Rappocini Raya Lr.II A No 13 Kota Makassar

Redaksi : JL. Muhktar dg Tompo Kabupaten Gowa Perumahan Nayla Regency Blok D No 25 https:/toharmedia.co.id
ISBN 978-623-7485-64-3

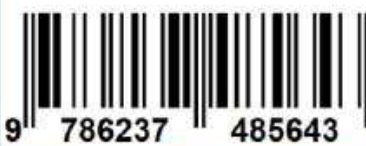

